\title{
Rekonstruksi formula perhitungan kompensasi bagi usaha perikanan budidaya yang terdampak pencemaran laut
}

\section{Reconstruction of the compensation calculation formula for impacted aquaculture by marine pollution}

Ali Mashar ${ }^{\text {ab }}$, Gatot Yulianto ab, Sugeng Hari Wisudo ${ }^{\text {bc }}$,Luluk Dwi Wulan Handayani ${ }^{\text {a }}$, Irza Arnita Nur a , Hadi Supardi ${ }^{\text {, }}$ Audra Ligafinza $^{\mathrm{d}}$, Luisa Febrina Amalo ${ }^{\mathrm{a}}$, Marfian Dwidima Putra ${ }^{\mathrm{a}}$, Yusli Wardiatno ${ }^{\mathrm{ab}}$, Hefni Effendi ${ }^{\text {ab }}$

${ }^{a}$ Pusat Penelitian Lingkungan Hidup, Lembaga Penelitian dan Pengabdian kepada Masyarakat, IPB University, Kampus IPB Dramaga Bogor, 16680, Indonesia

${ }^{\mathrm{b}}$ Departemen Manajemen Sumberdaya Perairan, Fakultas Perikanan dan Ilmu Kelautan, IPB University, Kampus IPB Dramaga Bogor, 16680, Indonesia [+62 251-8622932]

${ }^{\mathrm{c}}$ Departemen Pemanfaatan Sumberdaya Perikanan, Fakultas Perikanan dan Ilmu Kelautan, IPB University, Kampus IPB Dramaga Bogor, 16680, Indonesia

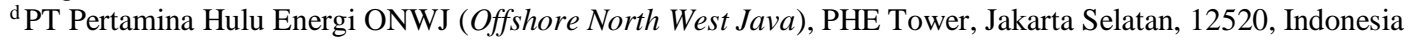

\section{Article Info:}

Received: 03 - 04 - 2021

Accepted: 03 - 06 - 2021

\section{Keywords:}

Aquacultures, compensation, formula, pollution

\section{Corresponding Author:}

Ali Mashar

Departemen Manajemen

Sumberdaya Perairan, Fakultas

Perikanan dan Ilmu Kelautan,

IPB University;

Tel. +62-251-8622932

Email:

alimashar75@gmail.com

\begin{abstract}
Marine pollution can have a negative impact on aquaculture. For this reason, an appropriate and precise compensation calculation formula is needed. This study aims to formulate a formula for compensation calculating for aquaculture by reconstructing formula in PermenLH No. 7/2014. The reconstruction of formula was analyzed descriptively qualitatively with an expert judgment approach. The results showed that production data was a key factor in the reconstruction of compensation calculation formula. There are three reconstruction results formulas, namely compensation formula for aquaculture whose production data is available before and after pollution; compensation formula for aquaculture, which only production data is available before pollution; and compensation formula for aquaculture production data are not available.
\end{abstract}

How to cite (CSE Style $8^{\text {th }}$ Edition):

Mashar A, Yulianto G, Wisudo SH, Handayani LDW, Nur IA, Supardi H, Ligafinza A, Amalo LF, Putra MD, Wardiatno Y, Effendi H. 2021. Rekonstruksi formula perhitungan kompensasi bagi usaha perikanan budidaya yang terdampak pencemaran laut. JPSL 11(2): 215-220. http://dx.doi.org/10.29244/jpsl.11.2.215-220.

\section{PENDAHULUAN}

Wilayah pesisir dan laut Indonesia menyimpan sumber daya alam dan lingkungan yang tinggi, baik berupa sumber daya hayati, sumber daya non hayati, sumber daya buatan, maupun berupa jasa-jasa lingkungan (Dahuri et al., 2008; Kay dan Adler, 1999). Berbagai kegiatan perekonomian juga telah berkembang di wilayah pesisir dan laut, diantaranya penambangan minyak dan gas (migas), penambangan pasir, perindustrian, jasa transportasi, dan perikanan, terutama perikanan tangkap dan perikanan budidaya (Triarso, 2012). Akan tetapi di sisi lain, wilayah pesisir dan laut Indonesia juga sangat rentan terhadap berbagai ancaman pencemaran. Pencemaran adalah masuknya zat pencemar atau polutan ke dalam lingkungan (Pankratz, 2001 dalam Meinarni, 2016). Peristiwa pencemaran laut kerap terjadi di Indonesia, baik yang berasal dari tumpahan 
minyak ( oil spill), tabrakan kapal dengan terumbu karang, pembuangan air limbah, aktivitas domestik manusia (marine debris), industri (pengolahan perikanan), perhubungan laut, maupun aktivitas lainnya. Kegiatan industri migas memiliki potensi yang cukup tinggi untuk terjadinya pencemaran lingkungan (Salahuddin $e t$ al., 2012).

Pencemaran laut ini dapat menimbulkan dampak negatif terhadap ekosistem pesisir dan laut (terumbu karang, lamun, dan mangrove), biota laut dan habitatnya, serta penurunan kualitas lingkungan pesisir. Jika tidak segera ditangani secara tepat, maka dampak negatif pencemaran laut tersebut akan semakin meluas, termasuk dampak terhadap kehidupan manusia, terutama terhadap kesejahteraan masyarakat yang ada di sekitarnya (Kusnandar, 2008 dalam Suwedi, 2017). Kehidupan manusia yang akan terdampak pencemaran laut adalah mereka yang menggantungkan hidupnya pada kesehatan lingkungan pesisir dan laut, diantaranya para pelaku usaha perikanan budidaya, baik budidaya pesisir atau tambak maupun budidaya laut atau marikultur. Aktivitas budidaya ikan tergantung dari kuantitas dan kualitas air, sebagai contoh pada tambak udang, kualitas air berpengaruh terhadap produktivitas polikultur udang vaname dan ikan bandeng (Hendrajat et al., 2018), sehingga adanya pencemaran perairan akan berdampak terhadap penurunan kualitas air dan pada akhirnya berpengaruh pada produksi budidaya.

Secara hukum, setiap kegiatan yang terdampak pencemaran, termasuk pencemaran laut, berhak untuk mendapatkan kompensasi, tidak terkecuali usaha perikanan budidaya (PermenLH No. 7 Tahun 2014). Pemberian kompensasi juga sebagai bentuk pertanggungjawaban ganti rugi dari pihak pelaku pencemaran (Kantaatmadja, 1981 dalam Sudini, 2015). Selain sebagai bentuk ganti rugi, kompensasi ini juga dapat mencegah terjadinya pergolakan di masyarakat terdampak pencemaran, tidak terkecuali pada para pelaku perikanan budidaya atau petambak (Istiana, 2013). PermenLH No. 7 Tahun 2014 memberikan formula perhitungan kompensasi atau ganti rugi bagi kegiatan perekonomian yang terdampak pencemaran. Akan tetapi, formula perhitungan yang diberikan masih bersifat umum, sehingga tidak bisa langsung digunakan untuk perhitungan kompensasi bagi kegiatan perikanan yang terdampak pencemaran laut, apalagi jenis dan kondisi kegiatan perikanan budidaya di wilayah pesisir dan laut sangat beragam. Oleh karena itu, dibutuhkan formula spesifik untuk perhitungan kompensasi kegiatan perikanan budidaya yang terdampak pencemaran di laut melalui rekonstruksi formula perhitungan kompensasi pada PermenLH No. 7 Tahun 2014.

Penelitian ini bertujuan untuk merumuskan formula-formula perhitungan kompensasi untuk usaha perikanan budidaya terdampak pencemaran laut dengan merekonstruksi formula yang terdapat di PermenLH No. 7 Tahun 2014. Formula-formula yang didapatkan dari rekonstruksi formula yang sudah ada ini diharapkan dapat bermanfaat sebagai landasan ilmiah dalam menghitung nilai kompensasi bagi kegiatan perikanan budidaya terdampak pencemaran laut.

\section{METODE}

\section{Metode Pengumpulan Data}

Data yang dikumpulkan pada studi ini adalah formula umum untuk menghitung kompensasi bagi kegiatan perekonomian yang terdampak pencemaran yang tedapat di PermenLH No. 7 Tahun 2014. Formula perhitungan kompensasi ini dirumuskan dengan pendekatan pendapatan faktor (factor income approach) yang dihitung melalui perubahan rente ekonomi atau surplus. Formula tersebut adalah sebagai berikut:

$$
\text { Rent }=((P b \times Q b)-\text { Biaya rata }- \text { rata/output }) \text { sebelum }-((P s \times Q s)-\text { Biaya rata }- \text { rata/output }) \text { sesudah }
$$

\section{Keterangan:}

$\mathrm{Pb}=$ Harga produk sebelum terjadi kerusakan,

Ps = Harga produk setelah terjadi kerusakan,

$\mathrm{Qb}=$ Produksi sebelum terjadi pencemaran/kerusakan,

Qs = Produksi setelah terjadi pencemaran/kerusakan. 


\section{Metode Analisis Data}

Analisis data yang dilakukan adalah rekonstruksi formula PermenLH untuk menghasilkan formulaformula perhitungan kompensasi khusus kegiatan perikanan budidaya. Analisis data dilakukan secara deskriptif kualitatif dengan pendekatan expert judgement. Rekonstruksi formula ini mempertimbangkan kelengkapan atau kecukupan ketersediaan data-data produksi perikanan budidaya sebelum dan sesudah kejadian pencemaran laut, lama waktu pencemaran laut, serta fakta dampak pencemaran laut terhadap kegiatan perikanan budidaya di wilayah pesisir dan laut.

\section{HASIL DAN PEMBAHASAN}

\section{Review Formula Umum}

Formula yang terdapat dalam PermenLH No. 7 Tahun 2014 untuk menghitung kompensasi bagi kegiatan perekonomian terdampak pencemaran masih bersifat umum, sehingga formula tersebut tidak bisa langsung digunakan untuk menghitung nilai kompensasi untuk kegiatan perikanan budidaya. Kalaupun bisa digunakan langsung, juga akan terbatas penggunaannya. Perhitungan dalam formula tersebut hanya mempertimbangkan variabel yang langsung berkaitan dengan produksi, yaitu jumlah dan harga produk, serta biaya produksi. Dalam kasus pencemaran laut, banyak faktor yang dapat mengakibatkan variasi dampak yang akan diterima kegiatan perikanan budidaya di wilayah pesisir dan laut, diantaranya sumber pencemar dan kondisi oseanografi.

Kondisi oseanografi, seperti gelombang, kecepatan dan arah arus di laut, serta perubahannya, terutama di pusat pencemaran laut, berpengaruh terhadap lama waktu dampak pencemaran laut. Kondisi fisika oseanografi tersebut dan posisi sumber atau pusat pencemaran berpengaruh terhadap sejauh mana pencemaran mencapai kawasan perikanan budidaya, baik budidaya laut maupun budidaya pesisir/tambak, sehingga tingkat keterdampakan kegiatan perikanan budidaya tersebut dapat berbeda-beda, dari yang terdampak berat hingga terdampak ringan. Kematian komoditas yang sedang dibudidayakan juga dapat terjadi ketika pencemaran laut mencapai kawasan perikanan budidaya, terutama budidaya laut. Kerusakan sarana dan prasarana budidaya juga dapat terjadi akibat pencemaran laut, seperti kerusakan jaring pada Keramba Jaring Apung (KJA), tali ris pada budidaya rumput laut, pintu air masuk tambak, dan pompa inlet pada tambak. Fakta-fakta yang kerap terjadi pada kejadian pencemaran laut tersebut seharusnya dipertimbangkan dalam menghitung nilai kompensasi kegiatan perikanan budidaya agar dihasilkan nilai kompensasi yang tepat nilai, akuntabel, dan dapat dipertanggungjawabkan, namun dalam formula PermenLH tersebut diperhitungkan.

Selain itu, fakta bahwa sistem pendataan yang lemah pada para pelaku usaha perikanan di Indonesia, termasuk perikanan budidaya. Hasil kajian Bappenas (2014) memperkuat fakta ini bahwa salah satu permasalahan nasional dalam pengembangan usaha perikanan budidaya di Indonesia adalah sistem pendataan perikanan budidaya belum andal dan belum efisien. Sudah bukan menjadi rahasia umum lagi bahwa para pelaku usaha perikanan budidaya di Indonesia, terutama yang sifatnya mandiri atau perorangan dan teknologi tradisional, sering dijumpai tidak aware dalam pendataan, terutama dalam mendata dan menyimpan buktibukti transaksi yang terjadi dalam setiap musim tanam atau siklus produksi. Akibatnya biaya-biaya produksi yang dikeluarkan selama satu siklus produksi tidak diketahui secara pasti atau kalaupun diketahui hanya perkiraan, sehingga mempersulit dan menghambat perhitungan nilai kompensasi kegiatan perikanan budidaya ketika terdampak pencemaran.

Fakta kondisi sistem pendataan perikanan budidaya ini harus dipertimbangkan ketika akan menghitung nilai kompensasi. Apalagi dengan model formula umum yang terdapat di PermenLH tersebut, ketiadaan data biaya produksi dapat mengakibatkan nilai kompensasi yang dihasilkan dari perhitungan dengan formula tersebut bisa sangat bias, tidak tepat nilai, dan sulit dipertanggungjawabkan, serta nilainya bisa over estimate. Oleh karena itu, perlu dibangun formula perhitungan kompensasi yang praktis, ilmiah, dan dapat dipertanggungjawabkan, bagi para pelaku perikanan budidaya, termasuk formula untuk mengakomodir para pelaku perikanan budidaya yang tidak memiliki atau sangat terbatas data biaya-biaya produksinya. 


\section{Rekonstruksi Formula Perhitungan Kompensasi}

Rekonstruksi formula perhitungan kompensasi bagi kegiatan perikanan budidaya yang terdampak pencemaran laut dibangun berdasarkan expert judgement dengan memperhatikan hasil review terhadap formula umum dalam PermenLH No. 7 Tahun 2014. Paling tidak terdapat tiga hal yang menjadi pertimbangan dalam rekonstruksi formula perhitungan kompensasi tersebut, yaitu: 1) Lama terdampak; 2) Tingkat keterdampakan; dan 3) Ketersediaan data, khususnya data biaya-biaya produksi.

Satuan waktu lama terdampak dalam perhitungan kompensasi bisa berbeda-beda antar usaha perikanan. Adapun untuk usaha perikanan budidaya, satuan waktu lama terdampak yang digunakan adalah siklus atau musim tanam. Tingkat keterdampakan menggambarkan tingkat keparahan dampak pencemaran laut terhadap produksi perikanan budidaya. Tingkat keterdampakan digambarkan dengan persen dan ditentukan dengan mengamati sejauh mana pencemaran laut tersebut memasuki kawasan perikanan budidaya, baik dengan pengamatan secara langsung maupun bantuan peralatan atau teknologi tertentu, seperti drone atau citra satelit. Ketersediaan data produksi perikanan budidaya, terutama data biaya-biaya produksi, menjadi faktor kunci dalam menghitung nilai kompensasi kegiatan perikanan budidaya yang terdampak pencemaran laut.

Berkaitan dengan ketersediaan data produksi pada saat perhitungan nilai kompensasi untuk kegiatan perikanan budidaya, paling tidak dapat dikelompokkan menjadi tiga kategori, yaitu Data Lengkap, Cukup Lengkap, dan Data Tidak Lengkap. Kategori Data Lengkap artinya tersedia data produksi perikanan budidaya sebelum dan sesudah kejadian pencemaran laut. Kategori Data Cukup Lengkap artinya data produksi perikanan budidaya hanya tersedia sebelum kejadian pencemaran laut. Kategori Data Tidak Lengkap artinya tidak tersedia data produksi perikanan budidaya, baik sebelum maupun sesudah kejadian pencemaran laut.

Berdasarkan hasil review formula umum dan beberapa pertimbangan di atas, maka terdapat tiga formula hasil rekonstruksi untuk perhitungan nilai kompensasi kegiatan perikanan budidaya yang terdampak pencemaran laut, yaitu:

$$
\begin{aligned}
& \text { (1) } C V_{a q}=\left[\left(\left(P_{b} \times Q_{b}\right)-\left(Q_{b} \times C_{p b}\right)\right)-\left(\left(P_{s} \times Q_{s}\right)-\left(Q_{s} \times C_{p s}\right)\right)\right] \times L_{i} \times T_{d i} \\
& \text { (2) } C V_{a q}=\left[\left(\left(P_{b} \times Q_{b}\right)-\left(Q_{b} \times C_{p b}\right)\right)-I_{s}\right] \times L_{i} \times T_{d i} \\
& \text { (3) } C V_{a q}=\left[I_{b}-I_{s}\right] \times L_{i} \times T_{d i}
\end{aligned}
$$

\section{Keterangan:}

$$
\begin{array}{ll}
C V_{a q} & =\text { Nilai kompensasi }(\mathrm{Rp}) \\
P_{b} & =\text { Harga produk sebelum pencemaran }(\mathrm{Rp} / \mathrm{Kg}) \\
P_{s} & =\text { Harga produk setelah pencemaran }(\mathrm{Rp} / \mathrm{Kg}) \\
Q_{b} & =\text { Produksi sebelum pencemaran }(\mathrm{Kg}) \\
Q_{s} & =\text { Produksi setelah pencemaran }(\mathrm{Kg}) \\
C_{p b} & =\text { Biaya operasional produksi sebelum pencemaran }(\mathrm{Rp} / \mathrm{Kg}) \\
C_{p s} & =\text { Biaya operasional produksi setelah pencemaran }(\mathrm{Rp} / \mathrm{Kg}) \\
L_{i} & =\text { Tingkat atau persentase keterdampakan }(\%) \\
T_{d i} & =\text { Lama terdampak (siklus) } \\
I_{b} & =\text { Pendapatan bersih sebelum pencemaran }(\mathrm{Rp} / \text { siklus }) \\
I_{s} & =\text { Pendapatan bersih setelah pencemaran }(\mathrm{Rp} / \text { siklus })
\end{array}
$$

Ketiga formula tersebut di atas, secara teknis dapat digunakan untuk menghitung nilai kompensasi usaha perikanan budidaya yang terdampak pencemaran laut. Penggunaan salah satu dari tiga formula penghitungan kompensasi hasil rekonstruksi tersebut sangat tergantung dari ketersediaan data-data produksi. Dari sisi akurasi, formula pertama adalah formula yang paling akurat karena variabel-variabel yang digunakan untuk menghitung nilai kompensasi paling lengkap. Hasil perhitungan nilai kompensasi dari formula pertama juga akan lebih tepat nilai dan akuntabel dibanding dua formula lainnya. Oleh karena itu, ketika terjadi peristiwa 218 
pencemaran laut dan berdampak pada kegiatan perikanan budidaya di sekitarnya, maka kegiatan pengumpulan data harus didesain secara tepat agar data-data yang akan dikumpulkan dapat dipergunakan untuk menghitung nilai kompensasi dengan formula pertama. Hal ini dapat diberlakukan untuk semua jenis dan teknologi, serta pola pemeliharaan kegiatan perikanan budidaya, termasuk komoditas yang dibudidayakan. Akan tetapi, ketika data-data produksi perikanan budidaya yang terkumpul terbatas dan tidak memadai untuk menghitung nilai kompensasi dengan formula pertama, maka secara teknis penggunaaan formula dua atau formula tiga dapat menjadi pilihan selanjutnya.

Keterbatasan data-data produksi pada kegiatan perikanan budidaya di Indonesia peluangnya cukup tinggi. Hal tersebut dikarenakan sebagian besar kegiatan perikanan budidaya di Indonesia, dikelola secara mandiri atau perorangan, dan teknologi yang digunakan masih sederhana atau tradisional dan tradisional plus. Karakter kegiatan perikanan budidaya di Indonesia yang dikelola mandiri atau perorangan umumnya kurang peduli dengan pencatatan data-data terkait produksi perikanan budidaya secara rinci dan terarsipkan, termasuk pengarsipan bukti-bukti transaksi keuangan selama masa produksi, apalagi jika teknologi yang diterapkan masih tradisional atau tradisional plus. Bagi mereka yang penting cukup mengingat jumlah biaya yang sudah dikeluarkan untuk kegiatan perikanan budidaya dan jumlah nilai produksi atau panen yang didapatkan. Oleh karena itu, dalam praktiknya, boleh jadi formula dua atau formula tiga akan lebih banyak digunakan untuk menghitung nilai kompensasi kegiatan perikanan budidaya yang terdampak pencemaran laut. Dalam kondisi seperti ini, akuntabilitas atau ketepatan nilai kompensasi hasil perhitungan dengan formula dua atau formula tiga sangat tergantung pada kemampuan, ketelitian, dan pengalaman dari ahli atau tim yang diberi tugas untuk menghitung nilai kompensasi tersebut dalam menilai dan mengevaluasi data-data yang terbatas (expert judgement). Expert judgement dalam kondisi ini juga sangat penting ketika terdapat data-data yang tidak logis, baik karena disengaja maupun tidak disengaja, yang disampaikan para pelaku usaha perikanan budidaya. Datadata yang tidak logis tersebut dengan pendekatan expert judgement akan dikoreksi, dievaluasi, dan dijustifikasi ketika akan digunakan untuk perhitungan nilai kompensasi agar nilai kompensasi tidak bias atau tidak underatau overestimate.

\section{SIMPULAN}

Ketersediaan data-data produksi usaha perikanan budidaya menjadi faktor kunci dalam rekonstruksi formula untuk menghitung nilai kompensasi kegiatan perikanan budidaya yang terdampak pencemaran laut. Berdasarkan ketersediaan data-data produksi, terdapat tiga formula hasil rekonstruksi untuk menghitung nilai kompensasi kegiatan perikanan budidaya, yaitu formula kompensasi untuk kegiatan perikanan budidaya yang data produksinya lengkap (tersedia data produksi sebelum dan setelah pencemaran); formula kompensasi untuk kegiatan perikanan budidaya yang hanya tersedia data produksi sebelum pencemaran; dan formula kompensasi untuk kegiatan perikanan budidaya yang tidak tersedia data produksi.

\section{UCAPAN TERIMA KASIH}

Ucapan terima kasih disampaikan kepada Pertamina Hulu Energi (PHE) yang telah mendukung secara penuh dalam upaya rekonstruksi formula untuk menghitung nilai kompensasi bagi usaha perikanan secara umum yang terdampak pencemaran laut.

\section{DAFTAR PUSTAKA}

[Bappenas] Badan Perencanaan Pembangunan Nasional. 2014. Kajian Strategis Pengelolaan Perikanan Berkelanjutan. Jakarta (ID): Direktorat Kelautan dan Perikanan, Kementerian PPN/Bappenas.

[Kemen LH] Kementerian Lingkungan Hidup. 2014. Peraturan Menteri Negara Lingkungan Hidup (PermenLH) Republik Indonesia Nomor 7 tahun 2014 tentang Kerugian Lingkungan Hidup Akibat Pencemaran dan/atau Kerusakan Lingkungan Hdup. Jakarta (ID): Kemen LH. 
Dahuri R, Rais J, Ginting SP, Sitepu MJ. 2008. Pengelolaan Sumberdaya Wilayah Pesisir dan Lautan Secara Terpadu. Jakarta (ID): Pradya Paramita.

Hendrajat EA, Ratnawati E, Mustafa A. 2018. Penentuan pengaruh kualitas tanah dan air terhadap produksi total tambak polikultur udang vaname dan ikan bandeng di Kabupaten Lamongan, Provinsi Jawa Timur melalui aplikasi analisis jalur. Jurnal Ilmu dan Teknologi Kelautan Tropis. 10(1): 179-195.

Istiana. 2013. Alternatif kebijakan menghadapi pergolakan petambak akibat pencemaran perairan (Studi kasus pada petambak Ujung Pangkah Kabupaten Gresik). J Kebijakan Sosek KP. 3(1): 15-26.

Kay R, Alder J. 1999. Coastal Planning and Management. London (GB): E \& FN Spon.

Meinarni NPS. 2016. Upaya hukum dalam penyelesaian sengketa pencemaran lingkungan laut dalam kasus tumpahan minyak Montara di Laut Timor. Jurnal Magister Hukum Udayana. 5(4): 833-870.

Salahuddin, Fandeli C, Sugiharto E. 2012. Kajian pencemaran lingkungan di tambak udang Delta Mahakam. Jurnal Teknosains. 2(1): 1-70.

Sudini LP. 2015. Pengelolaan Pencemaran Laut di Indonesia. Surabaya (ID): Penerbit RA De Rozarie. 294 hlm.

Suwedi N. 2017. Model hubungan waktu terjadinya tumpahan minyak di suatu lokasi dengan bentuk sebarannya pada daerah terdampak studi kasus: tumpahan minyak di sekitar pesisir LhokseumaweNAD. Jurnal Teknologi Lingkungan. 18(1): 104-111.

Triarso I. 2012. Potensi dan peluang pengembangan usaha perikanan tangkap di pantura Jawa Tengah. Jurnal Saintek Perikanan. 8(1): 65-73. 